\title{
Vorwort / Preface
}

Der vorliegende fünfte Band setzt die Beiträge zur Islamischen Kunst und Archäologie aus den Kolloquien der Ernst Herzfeld-Gesellschaft fort, die jeweils einen Themenschwerpunkt oder verschiedene Themen der laufenden Forschung zur Diskussion stellen. Seit dem ersten Band vor neun Jahren haben sich die Verhältnisse in einigen Ländern, deren visuelle und materielle Kultur das Anliegen der Gesellschaft ist, beunruhigend verändert, während in Europa und anderenorts Offenheit und Austausch in Frage gestellt werden.

Dieser Band führt hingegen die europäische und internationale Dimension von Forschung und Wissenschaft und der Ernst Herzfeld-Gesellschaft vor Augen. Er versammelt eine Auswahl der angemeldeten Referate aus den Kolloquien an der Universität Zürich 2012 (organisiert von Markus Ritter, jetzt Universität Wien) und in der Real Fundación in Toledo 2013 (organisiert von Fernando Valdéz Fernández, Universidad Autónoma de Madrid). Ein Beitrag kommt aus dem Kolloquium 2010 in Bonn (organisiert von Martina Müller-Wiener, jetzt Universität Frankfurt am Main). Die Veranstaltungen in der Schweiz und in Spanien boten Gelegenheit, Themen der Kolleginnen und Kollegen dieser Länder und ihre spezifische Forschungslandschaft innerhalb Europas näher kennenzulernen, und ein Forum für Referentinnen und Referenten vieler anderer Orte. Das spiegelt sich im Inhaltsverzeichnis dieses Bandes: die akademischen Standorte der Autorinnen und Autoren liegen in Deutschland, Frankreich, Großbritannien, Iran, Österreich, der Schweiz, Spanien und der Türkei.

Die Aufsätze dieses Bandes sind unter drei Überschriften gesetzt, die einen Großteil der Themen der beiden Kolloquien repräsentieren: Architektur im Zusammenhang von Stadtund Siedlungsgeschichte; das Verhältnis von Bild und Text in literarischen und religiösen Schriften; und Werke und Perspektiven der Moderne im Verhältnis zu älteren Traditionen. Sie reichen geographisch von Spanien bis Zentralasien und haben Schwerpunkte in der Frühen Neuzeit und der Moderne; zwei Aufsätze behandeln Themen frühislamischer und frühmittelalterlicher Zeit. Der im Vergleich zu vorhergehenden Bänden breitere Raum für Themen der Moderne in diesem fünften Band spiegelt eine internationale Entwicklung der Forschung und geht mit einer verstärkten Reflexion der Historiographie von Kunstgeschichte und Archäologie in islamischen Ländern einher.

Die Vielfalt der Themen und Sprachen der Referate hat die Herausgeber vor Anforderungen gestellt, die nur pragmatisch anzugehen waren. Dieser Band bündelt die englisch- und deutschsprachigen Beiträge, für die Manuskripte eingereicht wurden. Dabei blieb den Autorinnen und Autoren jeweils die Wahl des Systems der Transliteration überlassen, das sie für ihren Beitrag als bestgeeignet ansehen.

Wir danken herzlich Fernando Valdéz Fernández für Unterstützung bei der Zusammenstellung der Beiträge aus dem Kolloquium in Toledo und Sarah Teetor (Universität Wien) für das Lektorat der englischsprachigen Texte. Großer Dank gilt der Historisch-Kulturwissenschaftlichen Fakultät der Universität Wien für Unterstützung bei der Fertigstellung des Manuskriptes und dem Reichert Verlag und Miriam Würfel für die Umsetzung in das vorliegende Buch.

This fifth volume of the series Beiträge zur Islamischen Kunst und Archäologie represents a continuation of the publication of papers on Islamic Art History and Archaeology delivered 
at the colloquia of the Ernst Herzfeld Society, which are devoted either to one specific theme or to diverse subjects. Some of the countries whose visual and material culture is the concern of the Society have faced unsettling changes since the first volume was published nine years ago, while in Europe and in other regions, openness and exchange are being called into question.

The present volume demonstrates the European and international dimensions of scholarly research and of the Ernst Herzfeld Society. It includes a selection of papers from the colloquia convened in 2012 at the University of Zurich (organized by Markus Ritter, now University of Vienna) and in 2013 at the Real Fundación in Toledo (organized by Fernando Valdéz Fernández, Universidad Autónoma de Madrid). One contribution is from the colloquium in Bonn 2010 (organized by Martina Müller-Wiener, now University of Frankfurt am Main). The venues in Switzerland and Spain provided an opportunity to engage with the research themes of local colleagues and their specific research environment within Europe, as well as a forum for speakers from many more countries. This is reflected in the list of contributors to the present volume, who are based in Austria, France, Germany, Great Britain, Iran, Spain, Switzerland, and Turkey.

The contributions are arranged under three headings that represent a large part of the themes in both colloquia: architecture in relation to urban history; relations between image and text in literary and religious writings; and the arts and perspectives of the Modern period in relation to earlier traditions. They cover a geographic range from Spain to Central Asia and focus on the Early Modern and Modern periods, while two deal with themes of the Early Islamic and Early Medieval periods. Compared to the previous volumes, this fifth volume gives more room to the Modern period, reflecting an international development of scholarship and coupled with increased reflection on the historiography of Art History and of Archaeology in Islamic lands.

The diversity of themes and languages constituted a challenge for the editors and required a pragmatic approach. This volume contains the English and German papers that were submitted. In each case, we left it to the author to decide the most appropriate system of transliteration.

We warmly thank Fernando Valdéz Fernández for his help in collecting contributions from the colloquium in Toledo, and Sarah Teetor (University of Vienna) for copyediting the articles in English. We are most grateful to the Faculty of Historical and Cultural Studies of the University of Vienna for support in preparing the manuscript, and to our publisher, the Reichert Verlag, and to Miram Würfel for turning it into this book.

Wien und St Andrews, im April 2017 